\title{
Poland as an inflation nutter: The story of successful output stabilization ${ }^{*}$
}

\author{
Maciej Ryczkowski ${ }^{1}$
}

\begin{abstract}
The goal of the paper is to verify whether the National Bank of Poland (NBP) follows pure inflation targeting. The contemporaneous and forward looking, numerous Taylor rules estimated with the OLS and GMM methods provided weak evidence of any significant importance attached by NBP to output stabilization in the reaction function. The strong focus of NBP on its primary target has led to a satisfactory performance of the central bank in stabilizing the real economy. This suggests the basic conclusion that pure inflation targeters may perform equally fine in stabilizing the real economy as countries which officially attach importance to output stabilization.
\end{abstract}

Key words: Taylor rule, National Bank of Poland's preferences, performance of output stabilization, inflation targeting, inflation-output trade-off

JEL classification: E52, E58, E30

\section{Introduction}

Implementation of inflation targeting (IT) reflects the recognition of low and stable inflation's benefits. Nevertheless, IT framework allows for combining inflation stabilization with discretion to respond to output fluctuations. Indeed, the general consensus is that short-term real economy stabilization supports long run price stability (Rudebusch and Svensson, 1999: 203-262). In Rogoff's (1985) proposal, the reaction function may be represented by deviations of output and inflation from socially desired levels. In this matter King (1997) distinguishes two extreme types of central banks' behaviour. An 'employment nutter' targets only output and does not bother about inflation, while 'inflation nutter' is entirely focused on inflation.

\footnotetext{
* Received: 23-06-2016; accepted: 9-12-2016

1 Assistant Professor, Nicolaus Copernicus University, Faculty of Economic Sciences and Management, Gagarina 13a, 87-100 Toruń, Poland. Scientific affiliation: monetary policy. Phone: +4860353 2394.E-mail: m_ryczkowski@umk.pl.
} 
Lack of permanent trade-off between employment and inflation makes the employment nutter strategy unsustainable and no major central bank follows that approach. Another extremity is an inflation nutter. Intuitively, importance attached to deviations of real output from its steady-state values is expected to be relatively greater in countries with dual mandate (Judd and Rudebusch, 1998) or with a good record of inflation history (De Brouwer and Gilbert, 2005), so that they are not afraid to lose credibility while exploiting short term Phillips' curve. A greater focus on inflation seems to be expected in central banks aiming to gain credibility, i.e., countries that recently experienced high inflation or when IT was introduced as a disinflation strategy, as it happened in Poland. However, even within such countries there are convincing reasons to expect a certain dose of output stabilization.

When Poland adopted IT in late 1998, price stability became a primary objective of NBP. After quick and successful disinflation, it could have been supposed that the gained credibility should allow NBP to stabilize output fluctuations without unanchoring inflation expectations. However, output stabilization officially plays no role in setting policy rates. Moreover, some authors argue that NBP assigns none or only slight importance to output gap stabilization. It raises doubts whether the Polish monetary policy maximizes social welfare by providing stable prices while decreasing output fluctuations at the same time.

The aim of this article is to verify whether the National Bank of Poland (NBP) follows pure inflation targeting. The article contributes to the literature as scarcely little research on monetary policy reaction functions is devoted to small, open, emerging market economies, such as the Polish one. The asset of the article is that the applied thick modeling approach (Granger and Jeon, 2004) allows to considerably increase the robustness of the results. The reason is that deciding the specification of the 'true' reaction function and the variables considered is hard. Additionally, although the 'inflation nutter' hypothesis is verified only for Poland, the results are used for the subsequent, not one-country-oriented discussion and concern a wider range of monetary policy regimes. In particular, the article adds evidence to the up-to date and unresolved issues of whether dual mandated central banks perform better in output stabilization than central banks without such statutory goals (Evans, 2014) and adds to discussion about optimal monetary policy (Rudebusch and Williams, 2016, Debortoli et al., 2015). The issue is particularly relevant today as the majority of the developed (Rosengren, 2014) and developing countries (Botrić, 2012) experience low inflation while their unemployment rates are above their estimates of full employment.

The research hypothesis is that NBP assigns significant importance to output stabilization while setting interest rates. The results are discussed through the lens of NBP's strategy of monetary policy and achievements in stabilizing the real economy. Considering the alleged inferiority of strict inflation 
targeting regimes, the rejection of the hypothesis would suggest that NBP should presumably have suboptimal output and employment performance and presumably inferior to countries with significant importance attached to output stabilization.

The remaining part of the article is organized as follows: the second section reviews the literature on NBP's symmetrical Taylor rules and discusses the alleged consequences for countries that target solely inflation and do not attach significant importance to output gap in their reaction functions, the third section describes the applied econometric models with their estimation methods, the fourth section includes the data description and estimates of the Taylor-type rules in Poland. The fifth section discusses the empirical results, followed by the summarized conclusions in the sixth section.

\section{Literature review}

The broad consensus both among academics and practitioners from central banks seems to be that central banks should attach some importance to real economic activity while maintaining their primary focus on price stability. Indeed, the majority of influential studies provide evidence and arguments in favour of assigning positive weight to resource utilization (Woodford 2003, Reifschneider et al., 2015, English et al., 2015). Although the exact values that ought to be attached to the output gap in interest setting differ across the literature, for instance Evans (2014) proposes 0.25, Woodford (2003) recommends 0.048, in all papers it is usually claimed that households' welfare benefits when the weight is slightly positive. Some economists go further and plea for assigning a considerably greater importance to resource utilization (Debortoli et al., 2015) or argue for dual mandate implementation (Rosengren, 2014, Friedman, 2008, Meyer, 2002). To sum up, the monetary policy of inflation nutters is considered to be suboptimal because it may lead to undesirable output and employment performance, ultimately decreasing houshold welfare.

Meanwhile, some empirical studies on NBP reaction function advocate that the output gap may be insignificant when setting interest rates. Such results are discrepant with generally accepted consensus. Possibly inferior performance at output stabilization of pure IT regimes seems to be reinforced in Poland as Fendel et al. (2011) argued that market participants expected NBP to stabilize both inflation and output gaps in the considered ex-ante Taylor rules. Thus, if NBP was indeed an inflation nutter, an inconsistency arises between the central bank's behaviour and its public assessment. This discrepancy may lead to misunderstandings with regard to the bank's decisions and decrease NBP's credibility. 
One could reasonably expect that the introduction of a free floating exchange rate in 2000, inflation under control and well anchored inflation expectations should give more room for output stabilization in Poland. On the contrary, Frömmel et al. (2011) ascertained that focus of NBP on deviations of inflation from the target became even stronger, while output gap coefficients' estimates turned out to be insignificant. Although according to some recent studies NBP assigns positive weight to output stabilization in the reaction function (Popescu, 2015, 2014, Caraiani, 2013), they seem to be in minority. Paez-Farell (2007) in six out of eight different specifications of a TR, obtained estimates of output gap coefficients to be statistically insignificant or relatively small otherwise. Similar results were reported by other authors (Sznajderska 2014, Baranowski, 2011, Vašiček, 2010). Orlowski (2008) ascertained that NBP had the most restrictive course of monetary policy among the considered countries in transition. A counterpart of NBP's monetary policy was the Czech monetary policy with a sensible balance between inflation control and output stabilization.

Unlike NBP, in many high developed countries the coefficient is argued to be positive and statistically significant (Paez-Farrell, 2015, Ilbas et al., 2013, Kam et al., 2009, Sauer et al., 2007, Assenmacher-Wesche, 2006). Nevertheless, quite surprisingly we may find papers providing evidence that some central banks from both advanced (Nikolsko-Rzhevskyy, 2011, Castelnuovo and Surico, 2004, Dennis, 2004) and emerging economies (Vašiček, 2010) may not attach significant ${ }^{2}$ importance to output gap stabilization, which seems hard to reconcile with the flexible IT framework (Svensson, 2009). This may raise doubts whether Poland and some other IT regimes with a strong focus on inflation control, such as, for instance, New Zealand, Canada or the United Kingdom, experience unfavourable results in terms of output and employment stabilization and, therefore, whether such regimes require institutional changes.

\section{Methodology and method of analysis}

We analyse NBP's reaction function by estimating contemporaneous and forward looking Taylor rules (Taylor, 1993) with interest smoothing (Clarida et al., 2000). In the search for reaction function with statistically significant output gap coefficient, we consider different measures of inflation, output gap, time spans, explanatory variables and estimation techniques to obtain a range of possible rules. Such simple rules in the opinion of Taylor and Williams (2010) have important robustness advantages over fully optimal or more complex rules and they work well in a variety of models. We search for symmetric effects in the reaction function, as it is argued that symmetrical IT helps to stabilize real output (Mishkin, 2001).

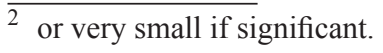


We consider the baseline scenario with $r_{t}$ denoting the NBP's reference rate in period $t$ and $r^{*}$ standing for the nominal rate if all descriptive variables would be at their target values:

$$
r_{t}=r^{*}+\sum_{k=1}^{m} \rho_{k} r_{t-k}+\beta\left(E\left\{\pi_{t+h} \mid \Omega_{t}\right\}-\bar{\pi}_{t}\right)+\gamma x_{t}
$$

where $\pi_{t+h}$ is the CPI annual inflation in period $t+h, \bar{\pi}_{t}$ is the inflation target in period $t, x_{t}$ is a measure of HP output gap $^{3}, E$ is the expectation operator, $\rho$ is a smoothing parameter and $\Omega_{t}$ denotes information set available to the central bank while setting the policy rate. We consider both $m=1$ and $m=2$ to eliminate serial correlation in the error term. Contemporaneous Taylor rules for $h=0$ are OLS estimated, while forward looking Taylor rules to provide for consistent estimations in rational expectations models are GMM estimated for $h=1$ and $h=4$. For $h=1$ as expectations are unobserved we assume two cases, the first one that the central bank is able to predict the survey-based, expected, four quarter inflation, i.e. $E\left\{\pi_{t+1} \mid \Omega_{t}\right\}$ $=E\left\{\pi_{t+5} \mid \Omega_{t+1}\right\}$ and the second is simply that $E\left\{\pi_{t+1} \mid \Omega_{t}\right\}=\pi_{t+1}$ (i.e., assuming that central bank is able to predict the inflation in the next quarter), while for $h=4$ we use survey-based four quarter inflation forecast $E\left\{\pi_{t^{+} 4} \mid \Omega_{t}\right\}$. Next, we expand the rule by deviations of USD and EUR exchange rates $\chi_{U S D}, \chi_{E U R}$ from their long run HP steady states $\left(\Phi_{U S D}\right.$ and $\left.\Phi_{E U R}\right)$ and by three dummies $\psi, \lambda$ and $\theta$ which take 1 ( 0 otherwise) during the disinflation period ${ }^{4}$, during exceptionally high policy rates ${ }^{5}$ and during forward guidance $(\mathrm{FG})^{6}$, respectively. Following Mehra's (1997) proposal we add secondary market yields of 10 year bonds $\vartheta_{t}$ as a proxy for expected short term rate assuming that $E\left\{\vartheta_{t} \mid \Omega_{t}\right\}=\vartheta_{t-1}$. The extended baseline specification takes the form:

$$
\begin{aligned}
& r_{t}=r^{*}+\sum_{k=1}^{m} \rho_{k} r_{t-k}+\beta\left(\mathrm{E}\left\{\pi_{t+h} \mid \Omega_{t}\right\}-\bar{\pi}_{t}\right)+\gamma x_{t}+\phi\left(\chi_{U S D}-\Phi_{U S D}\right)+ \\
& +\varphi\left(\chi_{E U R}-\Phi_{E U R}\right)+\alpha_{1} \psi+\alpha_{2} \lambda+\alpha_{3} \mathrm{E}\left\{\vartheta_{t} \mid \Omega_{t}\right\}+\alpha_{4} \theta+\varepsilon_{t}
\end{aligned}
$$

where $\phi, \varphi, \alpha_{1}, \alpha_{2}, \alpha_{3}$ and $\alpha_{4}$ are structural parameters and $\varepsilon_{t}$ is an error term.

Alternative GMM estimators may yield substantially different results (Jondeau et al., 2004), therefore to find a whole range of reaction functions we estimate the parameter vector by both two-step GMM and an iterative procedure. In GMM, if the sample is small, including more moment restrictions weakens the precision of the estimated weighting matrix (Andersen and Sørensen, 1996). Therefore, at the

3 (Real GDP - potential GDP)/ potential GDP. While Taylor (1993) used log linear trend of GDP, we follow in this respect Judd and Rudebusch (1998).

${ }^{4}$ Disinflation period lasted officially to $1 \mathrm{Q} 2004$.

5 Till 3Q 2005 reference rate was above 0.05 .

6 Between June 2013 and June 2014. 
beginning we include as instruments only lags of output gap, inflation gap and interest rate, which presumably enter the information set $\Omega_{t}$. However, we analyse other sets of instruments with their current ${ }^{7}$ or lagged values as well: exchange rates and their gaps, dummies $\psi, \lambda, \theta$ and secondary market yields of 10 year bonds $\vartheta$.

As robustness check we consider the output gap to be a percentage deviation from long-run polynomial trend, while for inflation we consider GDP implicit price deflator and core inflation indices. For core inflation measures, we assume that $E\left\{\pi_{t+1} \mid \Omega_{t}\right\}=\pi_{t+1}$ and $E\left\{\pi_{t+5} \mid \Omega_{t}\right\}=\pi_{t+5}$ as survey based expected values are unavailable. Afterwards, from the numerous specifications of the reaction function we exclude "unreasonable" outcomes ${ }^{8}$ and report on the estimates of the coefficients of the Taylor-type rules, which could help to reject the inflation nutter hypothesis. Some remaining examples of Taylor-type rules are reported in tables A1 and A2 in appendix. Before proceeding, we briefly address the assumption that the analysed variables are stationary. Stationarity of both inflation and nominal interest rate is a characteristic feature of many theoretical models extensively used by central banks (Clarida et al., 2000). Therefore, we also suspect stationarity of the considered time series, but to verify it we applied KPSS and ADF unit root tests.

\section{Empirical data and analysis}

We use quarterly data ranging from 1Q 2000 to 3Q 2015 for Poland. The exception were data for core inflation indices, which were available only from 2001 on, while data for Polish GDP deflator were available only to 3Q 2014. The selected time span covers the inflation targeting regime for Poland introduced in 1998. Nevertheless, the starting date of the analysis was selected two years later because up to 2000 a crawling band system functioned in Poland, which could have possibly altered the NBP's reaction function. To verify whether our analysis is time-invariant we perform estimations for the other two periods of time, i.e., from 1Q 2004 and from 3Q 2005 to 3Q 2015. The justification are the endings of the official disinflation period and of policy rates' lowering as well as Poland's accession to EU.

Policy rates (the NBP's reference rate), private sector's inflation expectations, core inflation indices (CPI net of administered prices, CPI net of most volatile prices, CPI net of food and energy prices and 15\% trimmed mean) and exchange rates data come from NBP, annual CPI inflation data (quarter to the analogous quarter of the previous year) were provided by CSO of Poland. Seasonally adjusted harmonized

\footnotetext{
Only exchange rates may be observed in the given quarter.

8 The unreasonable outcomes include negative or statistically insignificant estimates of the inflation gap's coefficient - which is an obvious violation of IT framework and is discrepant with the historical experience of NBP. We also exclude rules with considerably negative, but statistically significant estimated values of output gap's coefficient.
} 
unemployment rates and real GDP with its growth rates, GDP price deflator, and secondary market yields of 10 year bonds were taken from OECD. Data were used to construct a large set of Taylor-type rules for Poland and to assess NBP's performance. For all the variables, in spite of the problems with the persistence of the time series and the well-known low power of unit root tests, at least one test (KPSS, ADF) indicated stationarity (see: Table A3 in appendix). We believe this interpretation to be reasonable from the economic point of view in Poland after 2000. As a robustness check due to the initial disinflation period in Poland we estimated models for the first differences of the reference rate as well. The conclusions of the research were not altered. The conclusions were also not altered when considering shorter samples (after 2004 and 2005).

In our baseline scenario we have found only one contemporaneous rule (1) with statistically significant estimates of the output gap coefficient (Table 1).

Table 1: Selected baseline scenario estimates: Q1 2000 to Q3 2015

\begin{tabular}{|c|c|c|c|c|c|}
\hline Taylor-type Rule $^{\begin{array}{r}\text { Dep. var. } \\
\text { Diag. Tests }\end{array}}$ & $\hat{r}^{*}$ & $\hat{\rho}$ & $\hat{\beta}$ & $\hat{\gamma}$ & $\hat{\alpha}_{2}$ \\
\hline \multirow{2}{*}{ (1) contemporaneous } & $0.01(0.00)$ & $0.86(0.00)$ & $0.16(0.05)$ & $0.14(0.07)$ & $0.01(0.00)$ \\
\hline & \multicolumn{5}{|c|}{ R-squared: 0.99, Adjusted R-squared: 0.98, Durbin's h: 2.82.} \\
\hline \multirow[b]{3}{*}{ (2) contemporaneous } & \multirow{2}{*}{$0.00(0.00)$} & $1.16(0.13)$ & \multirow{2}{*}{$0.11(0.05)$} & \multirow{2}{*}{$0.09(0.06)$} & \multirow{2}{*}{$0.00(0.00)$} \\
\hline & & $-0.27(0.12)$ & & & \\
\hline & \multicolumn{5}{|c|}{$\begin{array}{l}\text { R-squared:0.99, Adjusted R-squared:0.98, DW:1.63, } \\
\text { Breusch-Godfrey test for autocorrelation up to order } 4 \\
\text { confirms no serial correlation. }\end{array}$} \\
\hline \multirow[b]{2}{*}{ (3) $E\left\{\pi_{t+1} \mid \Omega_{t}\right\}=E\left\{\pi_{t+5} \mid \Omega_{t+1}\right\}$} & $0.00(0.00)$ & $0.87(0.02)$ & $0.17(0.05)$ & $0.02(0.04)$ & - \\
\hline & \multicolumn{5}{|c|}{$\begin{array}{l}\text { two-step GMM, GMM criterion: } \mathrm{Q}=0.14 \text {, J test: } \\
\text { Chi-square }(6)=8.46[0.21] \text {, instruments: reference rate }(-1) \text {, } \\
\text { current exchange rates of PLN against EUR and USD, } \\
\text { lags } 1 \text { to } 3 \text { of inflation gap, and output gap. }\end{array}$} \\
\hline \multirow[b]{2}{*}{ (4) $E\left\{\pi_{t+1} \mid \Omega_{t}\right\}=\pi_{t+1}$} & $0.01(0.00)$ & $0.86(0.01)$ & $0.13(0.01)$ & $-0.02(0.02)$ & - \\
\hline & \multicolumn{5}{|c|}{$\begin{array}{l}\text { Iterated GMM, GMM criterion:Q }=0.18(\mathrm{~J} \text { test: Chi- } \\
\text { square }(16)=10.50[0.84] \text {, instruments:lagged reference rate, } \\
\text { lags } 1 \text { to } 3 \text { of inflation gap, output gap, current and lagged } \\
1 \text { to } 3 \text { exchange rates of PLN against EUR and USD. }\end{array}$} \\
\hline \multirow[b]{2}{*}{ (5) survey based $E\left\{\pi_{t+4} \mid \Omega_{t}\right\}$} & $0.01(0.00)$ & $0.86(0.02)$ & $0.12(0.05)$ & $0.04(0.04)$ & - \\
\hline & \multicolumn{5}{|c|}{$\begin{array}{l}\text { two-step GMM, GMM criterion: } \mathrm{Q}=0.14 \text {, J test: Chi- } \\
\text { square }(6)=8.63[0.20] \text {, instruments: lagged reference rate, } \\
\text { lags } 1 \text { to } 3 \text { of inflation gap, output gap. }\end{array}$} \\
\hline
\end{tabular}

Note: [p-values] in square brackets. (-) not considered, (standard errors) in round parenthesis, the dummy variable $\lambda$ was added.

Source: The author's own calculations on Gretl Software (v. 1.9.92) 
Nevertheless, in (1) we rejected the hypothesis of no serial correlation, which suggests that (1) may be spurious regression, which is a frequent problem for Taylor rules (Österholm, 2005). Evidently, in this matter contemporaneous rule (2) with two lags of policy rates is superior to (1), but with a statistically insignificant estimate of the output gap coefficient (Table 1).

Table 2: Selected baseline scenario estimates: Q1 2004 to Q3 2015

\begin{tabular}{|c|c|c|c|c|c|}
\hline Taylor-type Rule ${ }^{\begin{array}{l}\text { Dep. var. } \\
\text { Diag. Tests }\end{array}}$ & $\hat{r}^{*}$ & $\hat{\rho}$ & $\hat{\beta}$ & $\hat{\gamma}$ & $\hat{\phi}$ \\
\hline \multirow[b]{2}{*}{ (6) contemporaneous } & $0.01(0.00)$ & \begin{tabular}{|c|}
$1.04(0.16)$ \\
$-0.33(0.14)$ \\
\end{tabular} & $0.19(0.06)$ & $\begin{array}{l}-0.06 \\
(0.04)\end{array}$ & $\begin{array}{l}-0.01 \\
(0.00)\end{array}$ \\
\hline & \multicolumn{5}{|c|}{$\begin{array}{l}\text { R-squared:0.94, Adjusted R-squared } 0.93, \mathrm{LM} \text { test for } \\
\text { autocorrelation up to order } 4, \mathrm{LMF}=2.26, \mathrm{P}(\mathrm{F}(4,35)>2.26) \\
{[0.08] \text {. }}\end{array}$} \\
\hline \multirow[b]{2}{*}{ (7) $E\left\{\pi_{t+1} \mid \Omega_{t}\right\}=E\left\{\pi_{t+5} \mid \Omega_{t+1}\right\}$} & $0.01(0.00)$ & $0.84(0.04)$ & $0.13(0.03)$ & $-0.12(0.11)$ & - \\
\hline & \multicolumn{5}{|c|}{$\begin{array}{l}\text { Iterated GMM, GMM criterion:Q=0.17, J test: } \\
\text { Chi-square }(7)=7.55[0.37] \text {, instruments: lagged reference } \\
\text { rate, lags } 1 \text { to } 2 \text { of inflation gap, output gap, exchange rate } \\
\text { gaps of PLN against EUR and USD. }\end{array}$} \\
\hline \multirow[b]{2}{*}{ (8) $E\left\{\pi_{t+1} \mid \Omega_{t}\right\}=\pi_{t+1}$} & $0.00(0.00)$ & $0.97(0.07)$ & $0.05(0.06)$ & $0.03(0.05)$ & - \\
\hline & \multicolumn{5}{|c|}{$\begin{array}{l}\text { 2-step GMM, GMM criterion: } \mathrm{Q}=0.15 \text {, J test: Chi- } \\
\text { square }(10)=6.65[0.76] \text {, instruments: lagged reference rate, } \\
\text { lags } 1 \text { to } 3 \text { of inflation gap, output gap, exchange rate gaps } \\
\text { of PLN against EUR and USD. }\end{array}$} \\
\hline \multirow[b]{2}{*}{ (9) survey based $E\left\{\pi_{t+4} \mid \Omega_{t}\right\}$} & $0.01(0.00)$ & $0.83(0.04)$ & $0.11(0.04)$ & $-0.03(0.09)$ & - \\
\hline & \multicolumn{5}{|c|}{$\begin{array}{l}\text { two-step GMM, GMM criterion: } \mathrm{Q}=0.18 \text {, J test: } \\
\text { Chi-square }(7)=7.93 \text { [0.34], instruments: lagged reference } \\
\text { rate, lags } 1 \text { to } 2 \text { of inflation gap, output gap, exchange rate } \\
\text { gaps of PLN against EUR and USD. }\end{array}$} \\
\hline
\end{tabular}

Note: [p-values] in square brackets, (-) not considered, (standard errors) in round parenthesis. Source: The author's own calculations on Gretl Software (v. 1.9.92)

In appendix we placed more plausible examples of rules - all with statistically insignificant estimates of the output gap coefficient. Similarly, all versions and parameters' estimates of forward looking TRs do not allow us to accept the flexible inflation targeting hypothesis (see, for example: (3), (4) and (5) in Table 1).

Our evidence is robust with regard to the analysed time span. Neither for the period from 1Q 2004 to 3Q 2015 (Table 2) nor for the period from 3Q 2005 to 3Q 2015 (Table 3) we have not found single statistically significant estimate of the output gap coefficient. 
Table 3: Selected baseline scenario estimates: Q3 2005 to Q3 2015

\begin{tabular}{|l|c|c|c|c|c|}
\hline $\begin{array}{r}\text { Dep. var. } \\
\text { Diag. Tests }\end{array}$ & $\hat{r}^{*}$ & $\hat{\rho}$ & $\hat{\beta}$ & $\hat{\gamma}$ & $\hat{\phi}$ \\
\hline \multirow{3}{*}{ Taylor-type Rule } & $0.01(0.00)$ & $\frac{1.10(0.15)}{20)}$ contemporaneous & $0.13(0.03)$ & $0.07(0.05)$ & $-0.02(0.01)$ \\
\cline { 2 - 5 } & $\begin{array}{l}\text { R-squared:0.96, Adjusted R-squared:0.96, DW:1.50, } \\
\text { Breusch-Godfrey test for autocorrelation up to order } 4 \\
\text { confirms no serial correlation. }\end{array}$ \\
&
\end{tabular}

Note: For Forward Looking TRs the convergence criterion were not met or the results were implausible.

Source: The author's own calculations on Gretl Software (v. 1.9.92)

For alternative output gap measurement methods, different periods of time, alternative versions of contemporaneous and forward looking TR as well as for CPI net of administered prices, CPI net of food and energy prices and 15\% trimmed mean, we have not found a single reliable rule with significant estimate of the output gap coefficient. For CPI net of most volatile prices we report on three contemporaneous TRs $(11,12,13)$ in Table 4 and for GDP deflator we have one contemporaneous (14) and one forward looking (16) TR with significant output gap's coefficient (Tables 4, $5)^{9}$. The evidence of $\hat{\gamma}$ significancy are, however, quite weak.

Table 4: Selected alternative scenarios' estimates for CPI net of most volatile prices: Q1 2001 to Q3 2015

\begin{tabular}{|c|c|c|c|c|c|c|}
\hline $\begin{array}{r}\text { Dep. var. } \\
\text { Diag. Tests } \\
\text { Taylor-type Rule }\end{array}$ & $\hat{r}^{*}$ & $\hat{\rho}$ & $\hat{\beta}$ & $\hat{\gamma}$ & $\alpha_{2}$ & $\hat{\phi}$ \\
\hline \multirow{2}{*}{ (11) contemporaneous } & $0.01(0.00)$ & $0.80(0.03)$ & $0.10(0.05)$ & $0.14(0.05)$ & $0.01(0.00)$ & - \\
\hline & \multicolumn{6}{|c|}{ R-squared: 0.98, Adjusted R-squared: 0.98, Durbin's h: 1.48.} \\
\hline \multirow{2}{*}{ (12) contemporaneous } & $0.01(0.00)$ & $0.80(0.03)$ & $0.12(0.05)$ & $0.10(0.05)$ & $0.01(0.00)$ & - \\
\hline & \multicolumn{6}{|c|}{ R-squared: 0.98, Adjusted R-squared: 0.98, Durbin's h: 1.80.} \\
\hline \multirow{2}{*}{ (13) contemporaneous } & $0.01(0.00)$ & $0.80(0.03)$ & $0.10(0.05)$ & $0.09(0.05)$ & $0.01(0.00)$ & $-0.02(0.01)$ \\
\hline & \multicolumn{6}{|c|}{ R-squared: 0.98, Adjusted R-squared: 0.98, Durbin's h: 1.26.} \\
\hline
\end{tabular}

Source: The author's own calculations on Gretl Software (v. 1.9.92)

$\overline{9}$ TR(12) and TR(13) used percentage deviation from the long-run polynomial trend as the output gap, while remaining TR from Tables 4 and 5 used deviations from HP filtered values. 
First, statistical significance of $\hat{\gamma}$ in $(11,12,13)$ in Table 4 is no longer ascertained after removal of $\lambda$ dummy variable. Additionally, in analogous forward looking rules $\hat{\gamma}$ is insignificant. When contemporaneous and forward looking rules are discrepant with each other, as in this example, it seems appropriate to treat the results of the latter as more reliable. Numerous researchers claim that forward looking reaction function is constistent with the observations of central banks' behaviour (Clarida et al., 2000) and of NBP (Brzoza-Brzezina et al., 2013), while forward lookingness is expected from the normative point of view (Haldane and Batini, 1998, Svensson, 1997). Moreover, the results of $(11,12,13)$ do not have the required stability. In analogous contemporaneous and forward looking rules for the period since 2004 onwards, the estimates of the output gap coefficient turned out to be insignificant.

Table 5: Selected alternative scenarios' estimates for GDP deflator: Q1 2000 to Q3 2014

\begin{tabular}{|c|c|c|c|c|c|}
\hline Taylor-type Rule ${ }^{\begin{array}{l}\text { Dep. var. } \\
\text { Diag. Tests }\end{array}}$ & $\hat{r}^{*}$ & $\hat{\rho}$ & $\hat{\beta}$ & $\hat{\gamma}$ & $\hat{\phi}$ \\
\hline \multirow[b]{2}{*}{ (14) contemporaneous } & $0.00(0.00)$ & $0.95(0.02)$ & $0.14(0.07)$ & $0.10(0.05)$ & - \\
\hline & \multicolumn{5}{|c|}{$\begin{array}{l}\text { R-squared: } 0.98 \text {, Adjusted R-squared: } 0.98, \mathrm{LM} \text { test for } \\
\text { autocorrelation up to order } 4, \mathrm{LMF}=2.97, \mathrm{P}(\mathrm{F}(4,50)>2.97) \\
\text { [0.03], Durbin's h: } 2.89 \text {. }\end{array}$} \\
\hline \multirow[b]{3}{*}{ (15) contemporaneous } & \multirow{2}{*}{$0.00(0.00)$} & $1.33(0.13)$ & \multirow{2}{*}{$0.08(0.06)$} & \multirow{2}{*}{$0.05(0.05)$} & \multirow{2}{*}{ - } \\
\hline & & $-0.38(0.12)$ & & & \\
\hline & \multicolumn{5}{|c|}{$\begin{array}{l}\text { R-squared: } 0.98 \text {, Adjusted R-squared: } 0.98, \mathrm{LM} \text { test for } \\
\text { autocorrelation up to order } 4, \mathrm{LMF}=1.08, \mathrm{P}(\mathrm{F}(4,48)>1.08) \\
\text { [0.38], Durbin's h: }-0.79 .\end{array}$} \\
\hline \multirow[b]{2}{*}{ (16) $E\left\{\pi_{t+1} \mid \Omega_{t}\right\}=\pi_{t+1}$} & $0.01(0.00)$ & $0.87(0.01)$ & $0.07(0.03)$ & $0.09(0.02)$ & - \\
\hline & \multicolumn{5}{|c|}{$\begin{array}{l}\text { Iterated GMM, GMM criterion: } \mathrm{Q}=0.18, \mathrm{~J} \text { test: } \\
\text { Chi-square }(14)=9.68[0.78] \text {, instruments:lagged reference } \\
\text { rate, lags } 1 \text { to } 4 \text { of output gap, gdp deflator, exchange rate } \\
\text { gaps of PLN against EUR and USD. }\end{array}$} \\
\hline \multirow[b]{2}{*}{ (17) $E\left\{\pi_{t+1} \mid \Omega_{t}\right\}=\pi_{t+1}$} & $0.01(0.00)$ & $0.88(0.02)$ & $0.15(0.06)$ & $-0.02(0.04)$ & - \\
\hline & \multicolumn{5}{|c|}{$\begin{array}{l}\text { 2-step GMM, GMM criterion: } \mathrm{Q}=0.17, \mathrm{~J} \text { test: } \\
\text { Chi-square(14) }=9.21[0.82], \text { instruments from TR }(16) .\end{array}$} \\
\hline \multirow[b]{2}{*}{ (18) $E\left\{\pi_{t+1} \mid \Omega_{t}\right\}=\pi_{t+1}$} & $0.00(0.00)$ & $0.91(0.02)$ & $0.19(0.07)$ & $-0.04(0.06)$ & $-0.02(0.01)$ \\
\hline & \multicolumn{5}{|c|}{$\begin{array}{l}\text { 2-step GMM, GMM criterion: } \mathrm{Q}=0.17, \mathrm{~J} \text { test: } \\
\text { Chi-square(14) }=9.21[0.82] \text { instruments: lags } 1 \text { to } 3 \text { of } \\
\text { output gap, gdp deflator, current exchange rate of PLN against } \\
\text { EUR and their first and second lags. }\end{array}$} \\
\hline
\end{tabular}

Source: The author's own calculations on Gretl Software (v. 1.9.92) 
In (14) we rejected the hypothesis of no serial correlation, which suggests the rule is spurious regression. When we increased the lag of the reference rate up to $2, \hat{\gamma}$ became statistically insignificant $(15)^{10}$. In turn, (16) with a relatively low value of importance attached to inflation seems unreliable. Meanwhile, the long run impact of inflation gap on interest rates markedly lower than unity $(0.54)$ does not meet the Taylor principle of adjusting policy rates more proportionally than inflation. Such an outcome may be regarded as surprising in inflation targeting regimes (Popescu, 2014, Davig and Leeper, 2007), especially in Poland with strong disinflation attitude and considerable successes in controlling inflation. Interestingly in (17) where we used the same descriptive variables and instruments ${ }^{11}$, but once we estimated the parameter vector by two-step GMM (a more common approach when estimating TR), we received more reliable estimates of the inflation gap coefficient and at the same time insignificant role of the output gap in the reaction function (see, Table 5).

\section{Results and discussion}

In 1998, for the first time since the beginning of the transformation to a market economy, inflation in Poland fell to a single digit value of $8.6 \%$. No surprise then that the goal of newly implemented inflation targeting was further disinflation. NBP's strong attitude towards disinflation was clearly stated in official documents by acknowledging price stability as the primary objective of the monetary policy. Despite not hitting into the inflation bands between 1999 and 2003, price stability was achieved relatively soon. In consequence, since the beginning of 2004 the continuous inflation target has been set at $2.5 \%$ with a band for deviations of $+/-1$ percentage points. The problems with meeting the annual target band remained between 2004 and 2015, because in more than $70 \%$ of quarters the annual inflation was outside the target band. However, the overall inflation stabilization of NBP may be perceived as succesful as after 2004 the inflation was low and stable while the average inflation of $2.34 \%$ was very close to the middle of the range.

The majority of our estimations confirm the determination of monetary authorities to target inflation by meeting the Taylor principle ${ }^{12}$. Similarly, literature usually indicates a strong attitude of NBP towards inflation stabilization (Vašiček, 2012). The exceptional time with violated Taylor principle was evidenced by Baranowski and Gajewski (2016) during the annual period of FG, which they argue provided evidence for the credibility of this tool. In our forward looking estimations, FG was

\footnotetext{
${ }^{10}$ In (15) after the removal of the output gap, the inflation gap coefficient becomes statistically significant, value: 0.10 (std. err. 0.06 ) at p-value 0.08 .

${ }^{11}$ As well as in (18) (Table 5) where exchange rate gaps are added.

${ }^{12}$ All the models are first or second order autoregressive lag models, therefore, between the estimated coefficients and the long-run coefficients we have the following relation: $\hat{\beta}^{L R}=(1-\rho)^{-1} \beta$.
} 
significant but the coeffcient's estimates were very small (and positive). It seems to confirm that FG was credible and helped to make dicisions of NBP predictable. Nevertheless, the results may indicate that the implementation of FG was cautious as the tool was maintained only when the deviations from the bank's reaction function were small. The monetary policy stress (in the form of actual interest rates being far below the rule consistent levels) was therefore not an issue in Poland, contrary to the stance in euro area evidenced by Gajewski (2016) when ECB started following expansionary monetary policy after the Great Recession.

The inflation avoidance preferences of NBP are, however, not accompanied by any official statements associated with responsibilities for output stabilization. On the contrary, Article 227 of the Constitution of the Republic of Poland, states that NBP "shall be responsible for the value of the Polish currency". Only in the Act on NBP of 29 August 1997 one may find the vague expression that it should be done "while supporting the economic policy of the Government, insofar as this does not constrain the pursuit of the basic objective of NBP". Nevertheless, in the Monetary Policy Guidelines (NBP, 2015) it is explained that NBP contributes to sustainable economic growth in Poland by ensuring price stability.

Indeed, despite numerous estimations that we obtained following the thick modeling approach and despite the fact that Taylor rules turned out to be sensitive to data, the estimation methods and samples, empirical results seem to indicate rejection of the hypothesis that NBP assigns significant importance to output stabilization while setting interest rates. Our results are in line, for instance, with Frömmel et al. (2011) and Vašiček (2010), whose estimations suggest that NBP may be one of the exceptional countries that belong to the group of inflation nutters, which as it seems, exist not only in theory - contrary to what could have been expected. It could indicate that NBP by focusing on inflation, may announce strong commitment to meet the inflation target and despite several years of inflation targeting experience, the bank still aims to increase its credibility.

To the author's knowledge, only few papers of Popescu $(2015,2014)$ and Caraiani (2013) provide evidence discrepant with ours. Their results might differ as the authors applied DSGE models and inserted into Taylor-type rules also private credit, real estate market prices or exchange rate. Meanwhile, there is no convincing evidence that the Polish monetary authorities 'leaned against the wind' (such a possibility was only signalled after the Great Recession in case asset bubble would appear, Grostal et al., 2015) and the evidence concerning the importance of exchange rate for NBP's decisions are mixed. NBP under the floating exchange rate regime may take interventions in the foreign exchange market in case they prove necessary for macroeconomic and financial stability. Nevertheless, a considerable weakening of the exchange rate's pass through on CPI inflation was evidenced within last years. The downgraded role of this channel has largely structural 
character assosiated with growing contribution of international companies to the output (Kapuściński et al., 2016, p. 12).

As opposed to the exchange rate channel, the impact of NBP's interest rates on consumer inflation is evidenced to remain relatively strong and stabile in Poland (Kapuściński et al., 2016, p. 12). The nominal interest rate remains the principal instrument of NBP's monetary policy and most important channel of the transimission mechanism (NBP, 2015). This increases the robustness of our conclusions concerning the estimated Taylor-type rules in spite of sometimes expressed believes about the interest channel's falling impact on inflation ${ }^{13}$. The relevance of the interest channel in Poland and nominal rates higher than in the euro area pose a threat that declining interest rates and easier financing conditions after the euroisation may cause boom-bust cycle in domestic demand or in asset prices (Brzoza-Brzezina, 2014). The threat outlines an important field for further research on possible, preventive measures.

Another concern was that the evidenced by us attaching no significant importance to output gap in the reaction function of NBP could lead to poor real economy stabilization. The fears are, however, largely dispelled by the data. NBP achieved favourable output stabilization performance ${ }^{14}$, also in comparison to other posttransition countries. For example, in the Czech Republic, a country with evidence of assigning positive weights to the output gap (Orlowski, 2008) where IT was implemented eight months earlier than in Poland, standard deviation of real GDP was considerably greater $(3 \%)$, however the fall in the unemployment rate was roughly the same. Similarly, other full-fledged inflation targeters empirically proved in some studies to be primarily concerned about inflation, like New Zealand (Paez-Farrell, 2015), Canada or the U.K. (Nikolsko-Rzhevskyy, 2011) achieve satisfactory stabilization results. In this respect the statement of Friedman (2008) that inflation targeting is unlikely to be consistent with pursuing price stability and real economy objectives seems to be false.

The conclusion is contradictory to the results, for example, of Debortoli et al. (2015) who by using the Smets and Wouters (2007) model established that the role of the output gap ought to be equal or even more important than of inflation in order to maximize the household welfare. Our results differ also from those, for instance, of Mishkin and Schmidt-Hebel (2007) who claim that non-inflation-targeters including dual mandated countries exhibit better macroeconomic performance and have more efficient monetary policy than the group of inflation targeters.

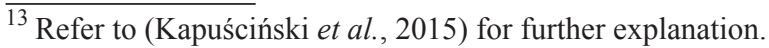

${ }^{14}$ Between 2000 and 2015 the overall fall of harmonized unemployment rate was more than $50 \%$ (from more than $15 \%$ to less than $8 \%$ ) and the standard deviation of the real GDP growth was $1.9 \%$, which was close to the value in United States (1.8\%) and less than in the United Kingdom (2.1\%), for instance.
} 
Nevertheless, their methodology has a crucial caveat that empirical analyses are not suited for Poland and presumably for some other inflation targeters too, as the authors base their judgement on quandratic loss function that includes besides quadratic output deviations also quadratic inflation deviations. In such an approach, even a successful disinflating strategy of Poland would make the Polish monetary policy inferior to monetary policies of countries with long history of a stable inflation. Therefore, in our opinion, if one wishes to include inflation behaviour into some indicator of economic performance, a more reliable variable for the countries where IT was implemented as a disinflation strategy, would be the magnitude of the achieved disinflation or some other measures that allow to account for initial conditions (such as, for example, high unemployment) (Lin and Ye, 2009).

The satisfactory results of NBP in terms of output stabilization may indicate that regardless of the formal status, NBP is dual-mandated 'at heart' (Rosengren, 2014) in the sense that output gap or unemployment rates may appear in the reaction function as forecasts of future inflation. That in turn would mean that the central bank does not need to follow dual mandated strategy to be successful at stabilizing the real economy as long as it bothers about meeting its primary goal of stabilizing inflation in a forward-looking fashion. As argued by Froyen and Guender (2012), a central bank ought to respond to optimal forecasts by using all available information, which includes real economy stance. If that was the case, it would explain the surprisingly satisfactory stabilization performance of NBP. Therefore, our evidence is in line with Putnam and Azzarello (2015) claiming that the effectiveness of monetary policy in aiming for full employment may be overstated. Ultimately central banks do not have control over real variables, like productivity, quality of the labour force, the entrepreneurial capacity of the business community or the availability of venture capital (Schwartz and Todd, 2008).

Our outcomes for Poland could be treated as evidence against assigning particular importance to output stabilization in the status of a central bank. Especially that to the tentative advantages, possible costs may be apposed. Besides, to those well known in the literature and mostly advocated by Friedman (1977) that include, among others, the risks for central bank independence (Meltzer, 2013), we may add some recent ones associated with undesired consumption dispersion during financial frictions (Lee, 2014) and risks associated with quantitative easing (Hoenig, 2011) that may lead to unintended consequences (White, 2012).

A more detailed study would be necessary in that field, as both external and internal factors including fiscal policy were not taken into account, while they exercise their impact on the economy with various strengths in particular countries (Krajewski, 2015, Trenovski and Tashevska, 2015, Yildirim et al., 2015). Nevertheless, our outcomes indicate that NBP seems to perform well in stabilizing the real economy despite no official importance attached to output stabilization policies. 


\section{Conclusion}

We were not able to accept the hypothesis that NBP assigns significant importance to output stabilization in its reaction function. Our empirical evidence indicates that the Polish central bank seems to follow pure inflation targeting strategy and meets the Taylor principle of adjusting policy rates more than proportionally with inflation in majority of estimations. Although it could rise concerns about the performance of the real economy, the conservative approach of NBP turned out to be working particularly well in practice. The article brings novelty in the evaluation of central banks' output stabilization achievements by providing new facts that the central bank without the resource utilization as a statutory goal may perform equally good or even better in terms of output stabilization than dual mandated regimes or flexible inflation tergeters. Meanwhile, the opposite conclusions were often evidenced in subject literature presumably because designed indicators were not appropriately adjusted for inflation targeting regimes which experienced periods of significant disinflation. The limits of the research are associated with various external and internal factors that may affect the performance of output stabilization, besides monetary policy. Therefore, future analyses ought to be extended by taking them into account, especially by including fiscal policy when assessing the performance of output stabilization. Additionally, the inflation avoidance preferences of NBP may pose a threat of a boom-bust cycle in domestic demand or in asset prices after joining the euro area. We leave this for further research. The satisfactory results of NBP in terms of output stabilization may indicate that the output gap or unemployment rate may appear in the reaction function as forecasts of future inflation. That in turn suggests that central banks may not need to follow dual mandated strategies to be successful at stabilizing the real economy as long as they bother about meeting their primary goal of stabilizing inflation in a forward-looking fashion. Therefore, assigning official importance to output stabilization seems to be questionable because possible costs and consequences may outweigh uncertain benefits.

\section{References}

Andersen, T. G., Sørensen, B. E. (1996) "GMM Estimation of a Stochastic Volatility Model: A Monte Carlo Study", Journal of Business and Economic Statistics, Vol. 14, No. 3, pp. 328-352, doi: 10.1080/07350015.1996.10524660.

Assenmacher-Wesche, K. (2006) "Estimating Central Banks' preferences from a time-varying empirical reaction function", European Economic Review, Vol. 50, No. 8, pp. 1951-1974, doi: 10.1016/j.euroecorev.2005.10.003.

Baranowski, P. (2011) "Reguła Polityki Pieniężnej dla Polski - Porównanie Wyników Różnych Specyfikacji”, Oeconomia Copernicana, Vol. 2, No. 3, pp. $5-21$. 
Baranowski, P., Gajewski, P. (2016) "Credible enough? Forward guidance and perceived National Bank of Poland's policy rule", Applied Economics Letters, Vol. 23, No. 2, pp. 89-92, doi: 10.1080/13504851.2015.1051651.

Botrić, V. (2012) "NAIRU estimates for Croatia", Zbornik radova Ekonomskog fakulteta u Rijeci, Vol. 30, No. 1, pp. 163-180.

Brzoza-Brzezina, M., Jacquinot, P., Kolasa, M. (2014) "Can We Prevent BoomBust Cycles During Euro Area Accession?" Open Economies Review, Vol. 25, No. 1, pp. 35-69, doi: 10.1007/s11079-013-9299-z.

Brzoza-Brzezina, M., Kotłowski, J., Miskowiec, A. (2013) "How forward looking are central banks? Some evidence from their forecasts", Applied Economics Letters, Vol. 20, No. 2, pp. 142-146, doi: 10.1080/13504851.2012.684780.

Caraiani, P. (2013) "Comparing monetary policy rules in CEE economies: A Bayesian approach", Economic Modelling, Vol. 32, pp. 233-246, doi: 10.1016/j. econmod.2013.01.045.

Castelnuovo, E., Surico, P. (2004) "Model Uncertainty, Optimal Monetary Policy and the Preferences of the Fed", Scottish Journal of Political Economy, Vol. 51, No. 1, pp. 105-126, doi: 10.1111/j.0036-9292.2004.05101007.x.

Clarida, R., Gali, J., Gertler, M. (2000) "Monetary policy and macroeconomic stability: evidence and some theory", The Quarterly Journal of Economics, Vol. 115, No. 1, pp. 147-180, doi: 10.1162/003355300554692.

Davig, T., Leeper, L. M. (2007) "Generalizing the Taylor Principle", American Economic Review, Vol. 97, No. 3, pp. 607-635, doi: 10.1257/aer.100.1.618.

De Brouwer, G., Gilbert, J. (2005) "Monetary Policy Reaction Functions in Australia", The Economic Record, Vol. 81, No. 253, pp. 124-134, doi: 10.1111/j.1475-4932.2005.00238.x.

Debortoli, D. et al. (2015) "Designing A Simple Loss Function For The Fed: Does The Dual Mandate Make Sense?" Federal Reserve Bank Of Boston Working Papers, No. 15-3.

Dennis, R. (2004) "Solving for optimal simple rules in rational expectations models", Journal of Economic Dynamics and Control, Vol. 28, No. 8, pp. 16351660, doi: 10.1016/S0165-1889(03)00097-6.

English, W. B., López-Salido, J. D., Tetlow, R. J. (2015) “The Federal Reserve's Framework for Monetary Policy: Recent Changes and New Questions", IMF Economic Review, Vol. 63, No. 1, pp. 22-70, doi: 10.1057/imfer.2014.27.

Evans, C. L. (2014) "Mainstream Economic Analysis and the Case for Accommodation", Journal of Money, Credit and Banking, Vol. 46, No. S2, pp. 143-154, doi: 10.1111/jmcb.12155.

Fendel, R., Frenkel, M., Rülke, J. C. (2011) ““"Ex-ante” Taylor rules and expectation forming in emerging markets", Journal of Comparative Economics, Vol. 39, No. 2, pp. 230-244, doi: 10.1016/j.jce.2011.01.001. 
Friedman, B. M. (2008) "Why a Dual Mandate is Right for Monetary Policy", International Finance, Vol. 11, No. 2, pp. 153-165, doi: 10.1111/j.14682362.2008.01220.x.

Friedman, M. (1977) "Nobel Lecture: Inflation and Unemployment", Journal of Political Economy, Vol. 85, No. 3, pp. 451-472, doi: 10.1086/260579.

Frömmel, M., Garabedian, G., Schobert, F. (2011) "Monetary Policy Rules in Central and Eastern European Countries: Does the Exchange Rate Matter?" Journal of Macroeconomics, Vol. 33, No. 4, pp. 807-818, doi: 10.1016/j.jmacro.2011.05.003.

Froyen, R. T., Guender, A. V. (2012) "Instrument versus Target Rules As Specifications of Optimal Monetary Policy", International Finance, Vol. 15, No. 1, pp. 99-123, doi: 10.1111/j.1468-2362.2012.01299.x.

Gajewski, P. (2016) "Monetary Policy Stress in EMU: What Role for Fundamentals and Missed Forecasts?", Emerging Markets Finance \& Trade, Vol. 52, No. 5, pp. 1226-1240, doi: 10.1080/1540496X.2015.1037204.

Granger, C. W. J., Jeon, Y. (2004) “Thick modeling”, Economic Modelling, Vol. 21, No. 2, pp. 323-343, doi: 10.1016/S0264-9993(03)00017-8.

Grostal, W., Ciżkowicz-Pękała, M., Niedźwiedzińska, J., Skrzeszewska-Paczek, E., Stawasz, E., Wesołowski, G., Żuk, P. (2015) Ewolucja strategii celu inflacyjnego w wybranych krajach, Warszawa: Narodowy Bank Polski.

Haldane, A., Batini, N. (1998) "Forward-Looking Rule for Monetary Policies", NBER Working Paper No. 6543.

Hoenig, T. M. (2011) “The Federal Reserve's Mandate: Long Run”, Business Economics, Vol. 46, No. 1, pp. 13-16, doi: 10.1057/be.2010.36.

Ilbas, P., Røisland, Ø., Sveen, T. (2013) "The influence of the Taylor rule on US monetary policy", Norges Bank Research Working Paper No. 04.

Jondeau, E., Le Bihan, H., Gallès, C. (2004) "Assessing Generalized Methodof-Moments Estimates of the Federal Reserve Reaction Function", Journal of Business \& Economic Statistics, Vol. 22, No. 2, pp. 225-239, doi: 10.1198/073500104000000118.

Judd, J. P., Rudebusch, G. D. (1998) "Taylor's Rule and the Fed:1970-1997", Federal Reserve Bank of San Francisco Economic Review, No. 3, pp. 3-16.

Kam, T., Lees, K., Liu, P. (2009) "Uncovering the Hit List for Small Inflation Targeters: A Bayesian Structural Analysis", Journal of Money, Credit and Banking, Vol. 41, No. 4, pp. 583-618, doi: 10.1111/j.1538-4616.2009.00224.x.

Kapuściński, M., Kocięcki, A., Kowalczyk, H., Łyziak, T., Przystupa, J., Stanisławska, E., Sznajderska, A., Wróbel, E. (2016), Mechanizm transmisji polityki pieniężnej w Polsce. Co wiemy w 2015 roku?, Warszawa: Narodowy Bank Polski.

King, M. (1997) "Changes in UK Monetary Policy: Rules and Discretion in Practice", Journal of Monetary Economics, Vol. 39, No. 1, pp. 81-97, doi: 10.1016/S0304-3932(97)00009-3. 
Krajewski, P. (2015) "Effectiveness of The Fiscal Policy in Stimulating Economy: The Case of Poland", Transformation in Business \& Economics, Vol. 14, No. 2 , pp. 53-67.

Lee, J. W. (2014) "Monetary policy with heterogeneous households and imperfect risk-sharing", Review of Economic Dynamics, Vol. 17, No. 3, pp. 505-522, doi: 10.1016/j.red.2013.09.002.

Lin, S., Ye, H. (2009) "Does inflation targeting make a difference in developing countries?", Journal of Development Economics, Vol. 89, No. 1, pp. 118-123, doi: 10.1016/j.jdeveco.2008.04.006.

Mehra, Y. (1997) “A Federal Funds Rate Equation”, Economic Inquiry, Vol. 35, No. 5, pp. 621-30, doi: 10.1111/j.1465-7295.1997.tb02038.x.

Meltzer, A. H. (2013) "What's Wrong with the Fed? What Would Restore Independence?" Business Economics, Vol. 48, No. 2, pp. 96-103, doi: 10.1057/ be.2013.7.

Meyer, L. H. (2002) "Inflation Targets and Inflation Targeting", The North American Journal of Economics and Finance, Vol. 13, No. 2, pp. 147-162, doi: 10.1016/ S1062-9408(02)00074-8.

Mishkin, F. S. (2002) Inflation targeting, An Encyclopedia of Macroeconomics, Cheltenham, UK and Northampton, MA, USA: Edward Elgar.

Mishkin, F. S., Schmidt-Hebel, K. (2007) "Does Inflation Targeting Make a Difference?", doi: 10.3386/w12876.

NBP, (2015) Monetary Policy Guidelines for 2016, Warsaw: Narodowy Bank Polski.

Nikolsko-Rzhevskyy, A. (2011) "Monetary Policy Estimation in Real Time: Forward-Looking Taylor Rules without Forward-Looking Data", Journal of Money, Credit and Banking, Vol. 43, No. 5, pp. 871-897, doi: 10.1111/j.15384616.2011.00400.x.

Orlowski, L. T. (2010) "Monetary Policy Rules for Convergence to the Euro", Economic Systems, Vol. 34, No. 2, pp. 148-159, doi: 10.1016/j.ecosys.2009.09.005. Österholm, P. (2005) "The Taylor Rule: A Spurious Regression?", Bulletin of Economic Research, Vol. 57, No. 3, pp. 217-247, doi: 10.1111/j.03073378.2005.01220.x.

Paez-Farrell, J. (2007) "Understanding monetary policy in Central European countries using Taylor-type rules: the case of the Visegrad four", Economics Bulletin, Vol. 5, No. 3, pp. 1-11.

Paez-Farrell, J. (2015), "Taylor rules, central bank preferences and inflation targeting”, The University of Sheffield Working Papers No. 2015023.

Popescu, I. V. (2014) "Analysis Of The Final Objectives Of Monetary Policy. The Case Of Central And Eastern European Countries", Studia Universitatis Babes-Bolyai Oeconomica, Vol. 59, No. 1, pp. 25-43, doi: 10.1016/S22125671(15)00105-7. 
Popescu, I. V. (2015) "A Structural Analysis of Central Banks Final Objectives Prioritization. The Case of Central and Eastern European States", Procedia Economics and Finance, Vol. 20, pp. 525-534, doi: 10.1016/S22125671(15)00105-7.

Putnam, B. H., Azzarello, S. (2015) "Evolving dynamics of the relationship between US core inflation and unemployment", Review of Financial Economics, Vol. 25, pp. 27-34, doi: 10.1016/j.rfe.2015.02.002.

Reifschneider, D., Wascher, W., Wilcox, D. (2015) “Aggregate Supply in the United

States: Recent Developments and Implications for the Conduct of Monetary Policy", IMF Economic Review, Vol. 63, No. 1, pp. 71-109, doi: 10.1057/imfer. 2015.1.

Rogoff, K. (1985) "The Optimal Degree of Commitment to an Intermediate Monetary Target", Quarterly Journal of Economics, Vol. 100, No. 4, pp. 1169 1189, doi: $10.2307 / 1885679$.

Rosengren, E. S. (2014) "Should Full Employment Be a Mandate for Central Banks?", Journal of Money, Credit and Banking, Vol. 46, No. S2, pp. 169-182, doi: $10.1111 /$ jmcb.12157.

Rudebusch, G. D., Svensson, L. E. O. (1999) "Policy Rules for Inflation Targeting". In Taylor, J. B. ed., Monetary Policy Rules, Chicago: University of Chicago Press.

Rudebusch, G. D., Williams, J. C. (2016) “A Wedge In The Dual Mandate: Monetary Policy And Long-Term Unemployment", Journal Of Macroeconomics, Vol. 47, pp. 5-18, doi: 10.1016/j.jmacro.2015.05.001.

Sauer, S., Sturm, J. E. (2007) "Using Taylor Rules to Understand European Central Bank Monetary policy", German Economic Review, Vol. 8, No. 3, pp. 375-398, doi: 10.1111/j.1468-0475.2007.00413.x.

Schwartz, A. J., Todd, W. F. (2008) "Why a Dual Mandate is Wrong for Monetary Policy", International Finance, Vol. 11, No. 2, pp. 167-183, doi: 10.1111/j.1468-2362.2008.01221.x.

Svensson, L. E. O. (1997) "Inflation Forecast Targeting: Implementing and Monitoring Inflation Targets”, European Economic Review, Vol. 41, No. (6), pp. 1111-1146, doi: 10.1016/S0014-2921(96)00055-4.

Svensson, L. E. O. (2009) "Flexible Inflation Targeting - Lessons From The Financial Crisis", Speech at the workshop "Towards a new framework for monetary policy? Lessons from the crisis", organized by the Netherlands Bank, Amsterdam. Available at: <http://www.bis.org/review/r090923d.pdf.>

Sznajderska, A. (2014) "On Asymmetric Effects in a Monetary Policy Rule. The Case of Poland", Economic Modelling, Vol. 36, pp. 547-556, doi: 10.1016/j. econmod.2013.09.045.

Taylor, J. B. (1993) "Discretion Versus Policy Rules in Practice", CarnegieRochester Conference Series on Public Policy, Vol. 39, pp. 195-214, doi: 10.1016/0167-2231(93)90009-1. 
Taylor, J. B., Williams, J. C. (2010) "Simple and Robust Rules for Monetary Policy". In Friedman, B. M., Woodford, M. ed., Handbook of Monetary Economics, Elsevier B.V.

Trenovski, B., Tashevska, B. (2015) "Fiscal or monetary dominance in a small, open economy with fixed exchange rate - the case of the Republic of Macedonia", Zbornik radova Ekonomskog fakulteta u Rijeci, Vol. 33, No. 1, pp. 125-145.

Vašiček, B. (2010) "Monetary Policy Rules and Inflation Processes in Open Emerging Economies", Eastern European Economics, Vol. 48, No. 4, pp. 36-58, doi: 10.2753/EEE0012-8775480402.

Vašiček, B. (2012) "Is Monetary Policy in the New EU Member States Asymmetric?", Economic Systems, Vol. 46, No. 2, pp. 235-263, doi: 10.1016/j. ecosys.2011.07.003.

White, W. R. (2012) "Ultra Easy Monetary Policy and the Law of Unintended Consequences", Federal Reserve Bank of Dallas Globalization and Monetary Policy Institute Working Paper No. 126.

Woodford, M. (2003) Interest and Prices, Princeton: Princeton University Press.

Yildirim, N., Ozcelebi, O., Ozkan, S. O. (2015) "Revisiting the impacts of oil price increases on monetary policy implementation in the largest oil importers", Zbornik radova Ekonomskog fakulteta u Rijeci, Vol. 33, No. 1, pp. 11-35. 


\title{
Poljska kao režim s ciljanom inflacijom: priča o uspješnoj stabilizaciji
}

\author{
Maciej Ryczkowski ${ }^{1}$
}

\begin{abstract}
Sažetak
Cilj rada je provjeriti slijedi li Narodna banka Poljske (NBP) čisti režim ciljanje inflacije. Suvremena i napredna gledišta brojnih Taylorovih pravila procijenjena uz pomoć OLS i GMM metoda pružaju slabe dokaze o svim značajnim čimbenicima koja NBP pripisuje u postizanju stabilizacije u reakcijskoj funkciji. NBP-ovo snažno fokusiranje na primarni cilj dovelo je do zadovoljavajućih rezultata središnje banke u stabiliziranju realnog gospodarstva što ukazuje na temeljni zaključak da režim ciljanje inflacije može jednako doprinijeti u stabiliziranju realnog sektora gospodarstva kao i u zemljama u kojima se službeno pridaje važnost izlaznoj stabilizaciji.
\end{abstract}

Ključne riječi: Taylorovo pravilo, postavke Narodne banke Poljske, rezultati izlazne stabilizacije, režim ciljane inflacije, balansiranje između inflacije $i$ proizvodnje

JEL klasifikacija: E52, E58, E30

${ }_{1}$ Docent, Nicolaus Copernicus University, Faculty of Economic Sciences and Management, Gagarina 13a, 87-100 Toruń, Poljska. Znanstveni interes: monetarna politika. Tel.: +48 60 353 2394.E-mail:m_ryczkowski@umk.pl. 



\section{Appendices}



Maciej Ryczkowski • Poland as an inflation nutter: The story of successful output...

Table A1: Examples of alternative contemporaneous regressions: Q1 2000 to Q3 2015

\begin{tabular}{|c|c|c|c|c|c|c|c|c|c|c|c|c|}
\hline \multicolumn{2}{|c|}{ Rule and fit } & $r^{*}$ & $\rho$ & $\beta$ & $\gamma$ & EX1 & EX2 & $\alpha_{1}$ & $\alpha_{2}$ & $\alpha_{3}$ & $\varphi$ & $\phi$ \\
\hline a1 & $\begin{array}{c}\text { R-sq: } 0.98 \text {, } \\
\text { Adj R-sq: } \\
0.99 \\
\text { Durbin's } \\
\text { h: } 3.28\end{array}$ & $\begin{array}{c}0.00 \\
(0.00)\end{array}$ & $\begin{array}{c}0.90 \\
(0.02)\end{array}$ & $\begin{array}{c}0.18 \\
(0.05) \\
C P I\end{array}$ & $\begin{array}{c}0.04 \\
(0.05) \\
H\end{array}$ & - & - & - & - & - & - & - \\
\hline $\mathrm{a} 2$ & $\begin{array}{c}\text { R-sq: } 0.98 \\
\text { Adj R-sq: } \\
0.98 \\
\text { Durbin's } \\
\text { h: } 3.32\end{array}$ & $\begin{array}{c}0.00 \\
(0.00)\end{array}$ & $\begin{array}{c}0.90 \\
(0.02)\end{array}$ & $\begin{array}{c}0.19 \\
(0.05) \\
C P I\end{array}$ & $\begin{array}{c}0.03 \\
(0.04) \\
P T\end{array}$ & - & - & - & - & - & - & - \\
\hline a3 & $\begin{array}{c}\text { R-sq: } 0.99 \\
\text { Adj R-sq: } \\
0.98 \\
\text { Durbin's } \\
\text { h: } 4.09\end{array}$ & $\begin{array}{c}0.00 \\
(0.01)\end{array}$ & $\begin{array}{c}0.80 \\
(0.06)\end{array}$ & $\begin{array}{c}0.28 \\
(0.08) \\
C P I\end{array}$ & $\begin{array}{c}0.06 \\
(0.05) \\
H P\end{array}$ & $\begin{array}{l}-0.01 \\
(0.00)\end{array}$ & $\begin{array}{c}0.01 \\
(0.00)\end{array}$ & - & - & $\begin{array}{c}0.01 \\
(0.08)\end{array}$ & - & - \\
\hline a3* & $\begin{array}{c}\text { R-sq: } 0.99 \\
\text { Adj R-sq: } \\
0.98 \\
\text { Durbin's } \\
\text { h: } 3.52\end{array}$ & $\begin{array}{l}-0.01 \\
(0.01)\end{array}$ & $\begin{array}{c}0.86 \\
(0.03)\end{array}$ & $\begin{array}{c}0.26 \\
(0.04) \\
C P I\end{array}$ & s.i. & s.i. & $\begin{array}{c}0.00 \\
(0.00)\end{array}$ & - & - & s. $i$. & - & - \\
\hline $\mathrm{a} 4$ & $\begin{array}{c}\text { R-sq: } 0.98 \\
\text { Adj R-sq: } \\
0.98 \\
\text { Durbin's } \\
\text { h: } 3.99\end{array}$ & $\begin{array}{c}0.00 \\
(0.01)\end{array}$ & $\begin{array}{c}0.80 \\
(0.05)\end{array}$ & $\begin{array}{c}0.29 \\
(0.07) \\
C P I\end{array}$ & $\begin{array}{c}0.04 \\
(0.04) \\
P T\end{array}$ & $\begin{array}{l}-0.01 \\
(0.00)\end{array}$ & $\begin{array}{l}-0.01 \\
(0.00)\end{array}$ & - & - & - & - & - \\
\hline a5 & $\begin{array}{c}\text { R-sq: } 0.99 \\
\text { Adj R-sq: } \\
0.98 \\
\text { Durbin's h: } \\
3.10\end{array}$ & $\begin{array}{c}0.01 \\
(0.01)\end{array}$ & $\begin{array}{c}0.84 \\
(0.04)\end{array}$ & $\begin{array}{c}0.18 \\
(0.06) \\
C P I\end{array}$ & $\begin{array}{c}0.13 \\
(0.07) \\
H P\end{array}$ & - & - & $\begin{array}{c}0.00 \\
(0.00)\end{array}$ & $\begin{array}{c}0.00 \\
(0.00)\end{array}$ & - & - & - \\
\hline a6 & $\begin{array}{c}\text { R-sq: } 0.99 \\
\text { Adj R-sq: } \\
0.98 \\
\text { Durbin's h: } \\
2.71\end{array}$ & $\begin{array}{c}0.00 \\
(0.00)\end{array}$ & $\begin{array}{c}0.87 \\
(0.05)\end{array}$ & $\begin{array}{c}0.15 \\
(0.07) \\
C P I\end{array}$ & $\begin{array}{c}0.13 \\
(0.07) \\
H P\end{array}$ & - & - & $\begin{array}{c}0.00 \\
(0.00)\end{array}$ & $\begin{array}{c}0.00 \\
(0.00)\end{array}$ & - & $\begin{array}{l}0.02 \\
(.02)\end{array}$ & $\begin{array}{c}-0.01 \\
(.01)\end{array}$ \\
\hline a7 & $\begin{array}{c}\text { R-sq: } 0.99 \\
\text { Adj R-sq: } \\
0.99 \\
\text { Durbin's } \\
\text { h: } 4.46\end{array}$ & $\begin{array}{c}0.01 \\
(0.01)\end{array}$ & $\begin{array}{c}1.11 \\
(0.13) \\
-0.34 \\
(0.11)\end{array}$ & $\begin{array}{c}0.24 \\
(0.07) \\
C P I\end{array}$ & $\begin{array}{c}0.07 \\
(0.07) \\
H P\end{array}$ & $\begin{array}{c}-0.01 \\
(0.00)\end{array}$ & $\begin{array}{c}0.01 \\
(0.00)\end{array}$ & - & $\begin{array}{c}0.00 \\
(0.00)\end{array}$ & - & - & - \\
\hline a8 & $\begin{array}{c}\text { R-sq: } 0.99 \\
\text { Adj R-sq: } \\
0.98 \\
\text { Durbin's } \\
\text { h: } 1.64\end{array}$ & $\begin{array}{c}0.01 \\
(0.00)\end{array}$ & $\begin{array}{c}1.18 \\
(0.13) \\
-0.32 \\
(0.13)\end{array}$ & $\begin{array}{c}0.16 \\
(0.06) \\
C P I\end{array}$ & $\begin{array}{c}0.06 \\
(0.07) \\
H P\end{array}$ & - & - & $\begin{array}{c}0.01 \\
(0.00)\end{array}$ & $\begin{array}{c}0.00 \\
(0.00)\end{array}$ & - & $\begin{array}{l}0.00 \\
(.02)\end{array}$ & $\begin{array}{c}-0.01 \\
(.01)\end{array}$ \\
\hline
\end{tabular}


Maciej Ryczkowski $\bullet$ Poland as an inflation nutter: The story of successful output... Zb. rad. Ekon. fak. Rij. • 2016 • vol. $34 \cdot$ no. $2 \cdot 363-392$

\begin{tabular}{|c|c|c|c|c|c|c|c|c|c|c|c|c|}
\hline \multicolumn{2}{|c|}{ Rule and fit } & $r^{*}$ & $\rho$ & $\beta$ & $\gamma$ & EX1 & EX2 & $\alpha_{1}$ & $\alpha_{2}$ & $\alpha_{3}$ & $\varphi$ & $\phi$ \\
\hline a9 & $\begin{array}{c}\text { R-sq: } 0.99 \\
\text { Adj R-sq: } \\
0.98 \\
\text { Durbin's } \\
\text { h: } 1.63\end{array}$ & $\begin{array}{c}0.00 \\
(0.00)\end{array}$ & $\begin{array}{c}1.16 \\
(0.13) \\
-0.28 \\
(0.12)\end{array}$ & $\begin{array}{c}0.11 \\
(0.05) \\
C P I\end{array}$ & $\begin{array}{c}0.09 \\
(0.07) \\
H P\end{array}$ & - & - & - & $\begin{array}{c}0.00 \\
(0.00)\end{array}$ & - & - & - \\
\hline a10 & $\begin{array}{c}\text { R-sq: } 0.99 \\
\text { Adj R-sq: } \\
0.98 \\
\text { Durbin's } \\
\text { h: } 1.53\end{array}$ & $\begin{array}{c}0.01 \\
(0.00)\end{array}$ & $\begin{array}{c}1.20 \\
(0.12) \\
-0.34 \\
(0.12)\end{array}$ & $\begin{array}{c}0.18 \\
(0.05) \\
C P I\end{array}$ & $\begin{array}{c}0.02 \\
(0.05) \\
H P\end{array}$ & - & - & $\begin{array}{c}0.01 \\
(0.00)\end{array}$ & - & - & - & - \\
\hline a11 & $\begin{array}{c}\text { R-sq: } 0.99 \\
\text { Adj R-sq: } \\
0.98 \\
\text { Durbin's } \\
\text { h: } 1.50\end{array}$ & $\begin{array}{c}0.01 \\
(0.00)\end{array}$ & $\begin{array}{c}1.21 \\
(0.12) \\
-0.35 \\
(0.12)\end{array}$ & $\begin{array}{c}0.18 \\
(0.05) \\
C P I\end{array}$ & $\begin{array}{c}0.02 \\
(0.04) \\
P T\end{array}$ & & & $\begin{array}{c}0.01 \\
(0.00)\end{array}$ & & & & \\
\hline a12 & $\begin{array}{c}\text { R-sq: } 0.99 \\
\text { Adj R-sq: } \\
0.99 \\
\text { Durbin's } \\
\text { h: } \\
-0.69\end{array}$ & $\begin{array}{c}0.05 \\
(0.03)\end{array}$ & $\begin{array}{c}0.75 \\
(0.10) \\
-0.17 \\
(0.08)\end{array}$ & $\begin{array}{c}0.41 \\
(0.05) \\
C P I\end{array}$ & $\begin{array}{c}0.05 \\
(0.04) \\
P T\end{array}$ & $\begin{array}{c}-0.05 \\
(0.01)\end{array}$ & $\begin{array}{c}0.05 \\
(0.01)\end{array}$ & - & - & - & $\begin{array}{l}0.18 \\
(.04)\end{array}$ & $\begin{array}{l}-0.16 \\
(.02)\end{array}$ \\
\hline a13 & $\begin{array}{c}\text { R-sq: } 0.99 \\
\text { Adj R-sq: } \\
0.99 \\
\text { Durbin's } \\
\text { h: }-0.69\end{array}$ & $\begin{array}{c}0.05 \\
(0.04)\end{array}$ & $\begin{array}{c}0.75 \\
(0.10) \\
-0.17 \\
(0.08)\end{array}$ & $\begin{array}{c}0.42 \\
(0.05) \\
C P I\end{array}$ & $\begin{array}{c}0.04 \\
(0.04) \\
P T\end{array}$ & $\begin{array}{c}-0.04 \\
(0.01)\end{array}$ & $\begin{array}{c}0.05 \\
(0.01)\end{array}$ & $\begin{array}{c}-0.01 \\
(0.00)\end{array}$ & - & - & $\begin{array}{l}0.17 \\
(.04)\end{array}$ & $\begin{array}{l}-0.15 \\
(.02)\end{array}$ \\
\hline a14 & $\begin{array}{c}\text { R-sq: } 0.98 \\
\text { Adj R-sq: } \\
0.98 \\
\text { Durbin's } \\
\text { h: } 1.50\end{array}$ & $\begin{array}{c}0.01 \\
(0.00)\end{array}$ & $\begin{array}{c}0.86 \\
(0.02)\end{array}$ & $\begin{array}{c}0.14 \\
(0.03) \\
A P\end{array}$ & $\begin{array}{c}-0.00 \\
(0.04) \\
H P\end{array}$ & - & - & - & - & - & - & - \\
\hline a15 & $\begin{array}{c}\text { R-sq: } 0.98 \\
\text { Adj R-sq: } \\
0.98 \\
\text { Durbin's } \\
\text { h: } 1.10\end{array}$ & $\begin{array}{c}0.01 \\
(0.00)\end{array}$ & $\begin{array}{c}0.87 \\
(0.02)\end{array}$ & $\begin{array}{c}0.11 \\
(0.04) \\
A P\end{array}$ & $\begin{array}{c}0.01 \\
(0.05) \\
H P\end{array}$ & - & - & - & - & - & $\begin{array}{l}0.01 \\
(.01)\end{array}$ & $\begin{array}{l}-0.01 \\
(.01)\end{array}$ \\
\hline a16 & $\begin{array}{c}\text { R-sq: } 0.98 \\
\text { Adj R-sq: } \\
0.98 \\
\text { Durbin's } \\
\text { h: } 0.87\end{array}$ & $\begin{array}{c}0.01 \\
(0.00)\end{array}$ & $\begin{array}{c}0.82 \\
(0.03)\end{array}$ & $\begin{array}{c}0.17 \\
(0.05) \\
A P\end{array}$ & $\begin{array}{c}-0.00 \\
(0.05) \\
H P\end{array}$ & - & - & $\begin{array}{c}0.01 \\
(0.00)\end{array}$ & - & - & $\begin{array}{l}0.00 \\
(.01)\end{array}$ & $\begin{array}{l}-0.01 \\
(.01)\end{array}$ \\
\hline a17 & $\begin{array}{c}\text { R-sq: } 0.99 \\
\text { Adj R-sq: } \\
0.99 \\
\text { Durbin's } \\
\text { h: }-0.33\end{array}$ & $\begin{array}{l}-0.01 \\
(0.04)\end{array}$ & $\begin{array}{c}0.64 \\
(0.05)\end{array}$ & $\begin{array}{c}0.21 \\
(0.05) \\
A P\end{array}$ & $\begin{array}{c}0.02 \\
(0.05) \\
H P\end{array}$ & $\begin{array}{c}-0.01 \\
(0.01)\end{array}$ & $\begin{array}{c}0.02 \\
(0.01)\end{array}$ & $\begin{array}{c}0.00 \\
(0.00)\end{array}$ & $\begin{array}{l}-0.01 \\
(0.00)\end{array}$ & $\begin{array}{c}0.18 \\
(0.08)\end{array}$ & $\begin{array}{l}0.05 \\
(.05)\end{array}$ & $\begin{array}{l}-0.09 \\
(.02)\end{array}$ \\
\hline
\end{tabular}


Maciej Ryczkowski • Poland as an inflation nutter: The story of successful output...

Zb. rad. Ekon. fak. Rij. • $2016 \cdot$ vol. $34 \cdot$ no. $2 \cdot 363-392$

\begin{tabular}{|c|c|c|c|c|c|c|c|c|c|c|c|c|}
\hline \multicolumn{2}{|c|}{ Rule and fit } & $r^{*}$ & $\rho$ & $\beta$ & $\gamma$ & EX1 & EX2 & $\alpha_{1}$ & $\alpha_{2}$ & $\alpha_{3}$ & $\varphi$ & $\phi$ \\
\hline $\mathrm{a} 17^{*}$ & $\begin{array}{c}\text { R-sq: } 0.99 \\
\text { Adj R-sq: } \\
0.99 \\
\text { Durbin's } \\
\text { h: } 0.18\end{array}$ & $\begin{array}{c}-0.06 \\
(0.01)\end{array}$ & $\begin{array}{c}0.65 \\
(0.04)\end{array}$ & $\begin{array}{c}0.19 \\
(0.04) \\
A P\end{array}$ & s.i. & s.i. & $\begin{array}{c}0.02 \\
(0.00)\end{array}$ & s.i. & $\begin{array}{l}-0.01 \\
(0.00)\end{array}$ & $\begin{array}{c}0.21 \\
(0.06)\end{array}$ & s. $i$. & $\begin{array}{l}-0.08 \\
(.02)\end{array}$ \\
\hline a18 & $\begin{array}{c}\text { R-sq: } 0.98 \\
\text { Adj R-sq: } \\
0.98 \\
\text { Durbin's } \\
\text { h: } 1.47\end{array}$ & $\begin{array}{c}0.01 \\
(0.00)\end{array}$ & $\begin{array}{c}0.86 \\
(0.02)\end{array}$ & $\begin{array}{c}0.15 \\
(0.03) \\
A P\end{array}$ & $\begin{array}{c}-0.01 \\
(0.03) \\
P T\end{array}$ & - & - & - & - & - & - & - \\
\hline a19 & $\begin{array}{c}\text { R-sq: } 0.98 \\
\text { Adj R-sq: } \\
0.98 \\
\text { Durbin's } \\
\text { h: } 1.57\end{array}$ & $\begin{array}{c}0.00 \\
(0.00)\end{array}$ & $\begin{array}{c}0.70 \\
(0.05)\end{array}$ & $\begin{array}{c}0.11 \\
(0.05) \\
A P\end{array}$ & $\begin{array}{c}0.00 \\
(0.04) \\
P T\end{array}$ & - & - & $\begin{array}{c}0.00 \\
(0.00)\end{array}$ & $\begin{array}{c}0.00 \\
(0.00)\end{array}$ & $\begin{array}{c}0.19 \\
(0.08)\end{array}$ & $\begin{array}{c}-0.02 \\
(.02)\end{array}$ & $\begin{array}{c}-0.01 \\
(.01)\end{array}$ \\
\hline a20 & $\begin{array}{c}\text { R-sq: } 0.98 \\
\text { Adj R-sq: } \\
0.97 \\
\text { Durbin's } \\
\text { h: } 2.64\end{array}$ & $\begin{array}{c}0.01 \\
(0.01)\end{array}$ & $\begin{array}{c}0.85 \\
(0.02)\end{array}$ & $\begin{array}{c}0.11 \\
(0.05) \\
M V\end{array}$ & $\begin{array}{c}0.03 \\
(0.04) \\
H P\end{array}$ & - & - & - & - & - & - & - \\
\hline a21 & $\begin{array}{c}\text { R-sq: } 0.97 \\
\text { Adj R-sq: } \\
0.97 \\
\text { DW: } 1.93\end{array}$ & $\begin{array}{c}0.00 \\
(0.00)\end{array}$ & $\begin{array}{c}1.17 \\
(0.14) \\
-0.29 \\
(0.12)\end{array}$ & $\begin{array}{c}0.06 \\
(0.05) \\
M V\end{array}$ & $\begin{array}{c}0.01 \\
(0.04) \\
H P\end{array}$ & - & - & - & - & - & - & - \\
\hline a22 & $\begin{array}{c}\text { R-sq: } 0.97 \\
\text { Adj R-sq: } \\
0.97 \\
\text { Durbin's } \\
\text { h: } 1.98\end{array}$ & $\begin{array}{c}0.00 \\
(0.00)\end{array}$ & $\begin{array}{c}1.23 \\
(0.13) \\
-0.34 \\
(0.12)\end{array}$ & $\begin{array}{c}0.03 \\
(0.07) \\
F E\end{array}$ & $\begin{array}{c}0.03 \\
(0.04) \\
H P\end{array}$ & - & - & - & - & - & - & - \\
\hline a23 & $\begin{array}{c}\text { R-sq: } 0.98 \\
\text { Adj R-sq: } \\
0.98 \\
\text { Durbin's } \\
\text { h: } 2.29\end{array}$ & $\begin{array}{c}0.01 \\
(0.00)\end{array}$ & $\begin{array}{c}0.85 \\
(0.02)\end{array}$ & $\begin{array}{c}0.15 \\
(0.05) \\
T M\end{array}$ & $\begin{array}{c}-0.00 \\
(0.05) \\
H P\end{array}$ & - & - & - & - & - & - & - \\
\hline a24 & $\begin{array}{c}\text { R-sq: } 0.97 \\
\text { Adj R-sq: } \\
0.97 \\
\text { DW: } 1.89\end{array}$ & $\begin{array}{c}0.00 \\
(0.00)\end{array}$ & $\begin{array}{c}1.12 \\
(0.14) \\
-0.25 \\
(0.12)\end{array}$ & $\begin{array}{c}0.10 \\
(0.05) \\
T M\end{array}$ & $\begin{array}{c}-0.00 \\
(0.04) \\
H P\end{array}$ & - & - & - & - & - & - & - \\
\hline a25 & $\begin{array}{c}\text { R-sq: } 0.99 \\
\text { Adj R-sq: } \\
0.99 \\
\text { Durbin's } \\
\text { h: } 1.37\end{array}$ & $\begin{array}{c}-0.03 \\
(0.04)\end{array}$ & $\begin{array}{c}0.57 \\
(0.06)\end{array}$ & $\begin{array}{c}0.25 \\
(0.07) \\
T M\end{array}$ & $\begin{array}{c}0.00 \\
(0.05) \\
H P\end{array}$ & $\begin{array}{c}-0.01 \\
(0.01)\end{array}$ & $\begin{array}{c}0.03 \\
(0.00)\end{array}$ & $\begin{array}{c}-0.00 \\
0.00\end{array}$ & $\begin{array}{c}-0.00 \\
(0.00)\end{array}$ & $\begin{array}{c}0.24 \\
(0.08)\end{array}$ & $\begin{array}{l}0.04 \\
(.05)\end{array}$ & $\begin{array}{l}-0.10 \\
(.02)\end{array}$ \\
\hline a26 & $\begin{array}{c}\text { R-sq: } 0.99 \\
\text { Adj R-sq: } \\
0.99 \\
\text { Durbin's } \\
\text { h: } 1.41\end{array}$ & $\begin{array}{c}-0.03 \\
(0.05)\end{array}$ & $\begin{array}{c}0.56 \\
(0.06)\end{array}$ & $\begin{array}{c}0.26 \\
(0.07) \\
T M\end{array}$ & $\begin{array}{c}-0.01 \\
(0.05) \\
H P\end{array}$ & $\begin{array}{c}-0.01 \\
(0.01)\end{array}$ & $\begin{array}{c}0.02 \\
(0.01)\end{array}$ & $\begin{array}{c}-0.00 \\
(0.00)\end{array}$ & $\begin{array}{c}-0.00 \\
(0.00)\end{array}$ & $\begin{array}{c}0.26 \\
(0.08)\end{array}$ & $\begin{array}{l}0.03 \\
(.06)\end{array}$ & $\begin{array}{r}-0.10 \\
(.02)\end{array}$ \\
\hline
\end{tabular}


Maciej Ryczkowski • Poland as an inflation nutter: The story of successful output... Zb. rad. Ekon. fak. Rij. $2016 \bullet$ vol. $34 \cdot$ no. $2 \cdot 363-392$

\begin{tabular}{|c|c|c|c|c|c|c|c|c|c|c|c|c|}
\hline \multicolumn{2}{|c|}{ Rule and fit } & $r^{*}$ & $\rho$ & $\beta$ & $\gamma$ & EX1 & EX2 & $\alpha_{1}$ & $\alpha_{2}$ & $\alpha_{3}$ & $\varphi$ & $\phi$ \\
\hline a27 & $\begin{array}{c}\text { R-sq: } 0.98 \\
\text { Adj R-sq: } \\
0.98 \\
\text { Durbin's } \\
\text { h: }-0.77\end{array}$ & $\begin{array}{c}0.00 \\
(0.00)\end{array}$ & $\begin{array}{c}1.34 \\
(0.13) \\
-0.39 \\
(0.12)\end{array}$ & $\begin{array}{c}0.08 \\
(0.06) \\
G D P\end{array}$ & $\begin{array}{c}0.04 \\
(0.04) \\
P T\end{array}$ & - & - & - & - & - & - & - \\
\hline a $28^{*}$ & $\begin{array}{c}\text { R-sq: } 0.98 \\
\text { Adj R-sq: } \\
0.98 \\
\text { DW: } 1.83\end{array}$ & $\begin{array}{c}0.00 \\
(0.00)\end{array}$ & $\begin{array}{c}1.33 \\
(0.12) \\
-0.42 \\
(0.12)\end{array}$ & $\begin{array}{c}0.15 \\
(0.07) \\
G D P\end{array}$ & $\begin{array}{c}0.04 \\
(0.04) \\
P T\end{array}$ & - & - & s.i. & s.i. & - & s.i. & s.i. \\
\hline
\end{tabular}

Note: EX1 denotes exchange rates of PLN against Euro, EX2 denotes zloty/US dollar exchange rate, HP index stays for Hodrick-Prescott filter, which was used to calculate the potential ouput, while PT stands for polynomial trend. (*) denotes respective estimates after the removal of statistically insignificant variables. Note that in some estimated equations we did not reject the no serial correlation hypothesis - therefore not all above 'rules' should be perceived as equally good alternative reaction functions (besides, the majority of the regressions include statistically insignificant estimates, which should be removed in a final versions of the reaction function). Nevertheless, in all the cases (except for those mentioned in the main text in section 'empirical results') the estimates of the output gap coefficient turned out to be statistically insignificant - and the output gap was in line with the a-posteriori method removed to obtain final estimations - however, to save space we do not report all of them. Statistically significant estimates (at 0.05 ) are bolded. AP stands for CPI net of administered prices, MV stands for CPI net of most volatile prices, FE stands for CPI net of food and energy prices, TM stands for $15 \%$ trimmed CPI mean (data for core inflation measures are since 1Q 2001), GDP stands for GDP deflator (data only to 3Q 2014).

Source: The author's own calculations on Gretl Software (v. 1.9.92) 
Maciej Ryczkowski $\bullet$ Poland as an inflation nutter: The story of successful output...

Zb. rad. Ekon. fak. Rij. • $2016 \cdot$ vol. $34 \cdot$ no. $2 \cdot 363-392$

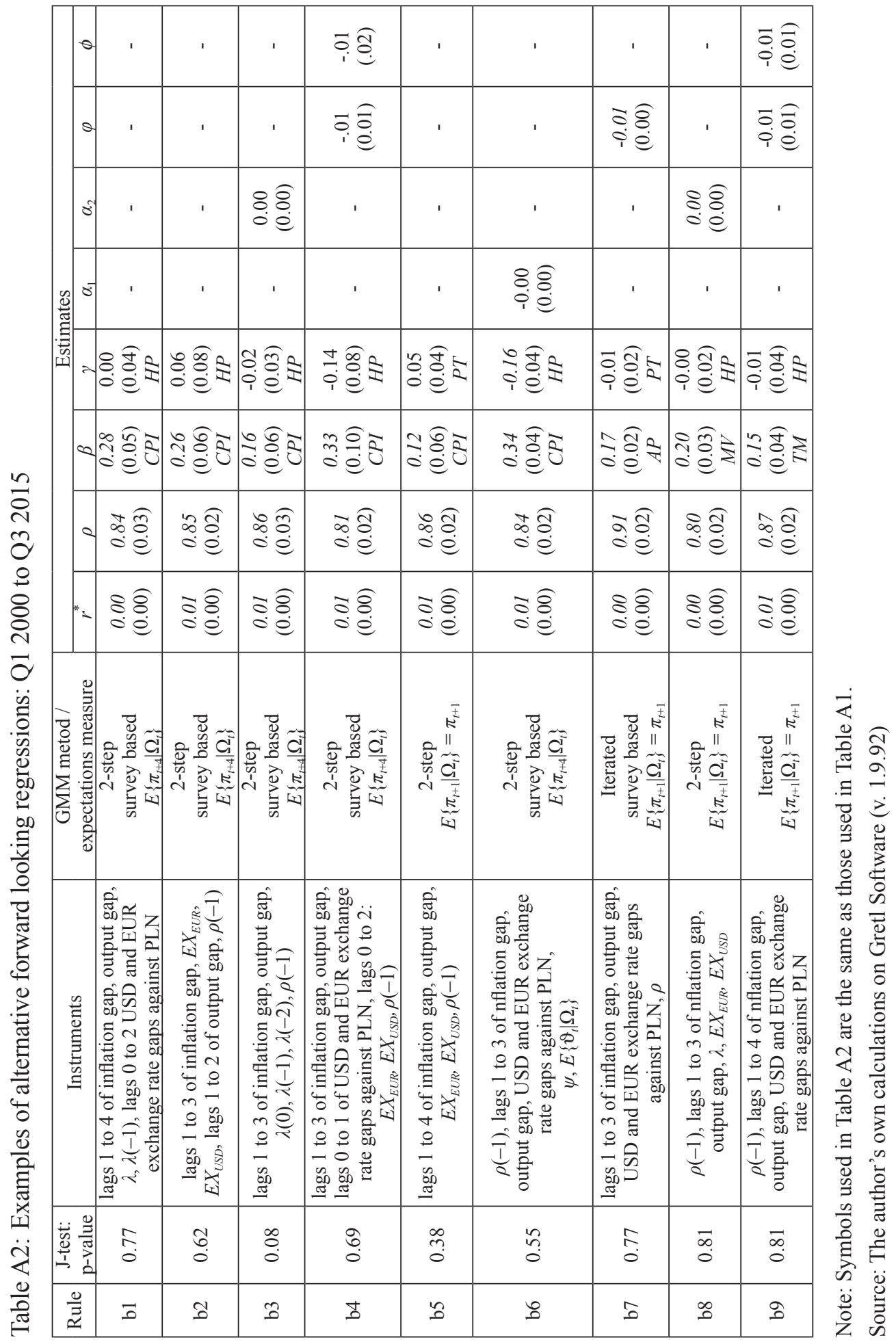


Table A3: Unit root tests: Q1 2000 - Q3 2015

\begin{tabular}{|c|c|c|c|}
\hline Variable & Symbol & $\begin{array}{c}\text { KPSS Test Statistic } \\
\text { (0.05 Critical Value: } \\
0.47)\end{array}$ & $\begin{array}{c}\text { KPSS Test Statistic } \\
\text { including trend } \\
\text { (0.05 Critical Value: } 0.15 \text {, } \\
0.01 \text { Critical Value: } 0.21)\end{array}$ \\
\hline Inflation gap & $\pi-\bar{\pi}$ & 0.16 & 0.13 \\
\hline Expected inflation gap & $E\left\{\pi_{t+h} \mid \Omega_{t}\right\}=\bar{\pi}_{t}$ & 0.31 & 0.13 \\
\hline Output gap (HP) & $x_{t}$ & 0.25 & 0.15 \\
\hline Alternative output gap ${ }^{\wedge}$ & $x_{t}$ & 0.26 & $\begin{array}{c}0.16 \text { (Interpolated p-value } \\
0.045 \text { ) }\end{array}$ \\
\hline NBP reference rate & $r_{t}$ & $\begin{array}{c}0.85 \\
\text { (ADF: test statistic: } \\
-3.02, \text { p-value: } 0.03 \text { ) }\end{array}$ & 0.21 \\
\hline USD/PLN gap & $\chi_{U S D}-\Phi_{U S D}$ & 0.17 & 0.14 \\
\hline EUR/PLN gap & $\chi_{E U R}-\Phi_{E U R}$ & 0.07 & 0.07 \\
\hline \multicolumn{2}{|c|}{ GDP deflator $^{\wedge}$} & 0.37 & 0.18 \\
\hline \multicolumn{2}{|c|}{ CPI net of administered prices ${ }^{*}$} & 0.20 & 0.15 \\
\hline \multicolumn{2}{|c|}{ CPI net of most volatile prices ${ }^{*}$} & 0.19 & 0.17 \\
\hline \multicolumn{2}{|c|}{ CPI net of food and energy prices ${ }^{*}$} & 0.14 & 0.15 \\
\hline \multicolumn{2}{|c|}{ Fifteen percent trimmed mean ${ }^{*}$} & 0.21 & 0.17 \\
\hline
\end{tabular}

Note: The table presents the results of Kwiatkowski-Philips-Schmidt-Shin (KPSS) test with the annual lag order; in case of the reference rate additional ADF test was reported, the Akaike Criterion was used to indicate the lag length selecting a lag of 8 quarters and testing down from the maximum lag order, *data since Q1 2001, ^ data only up to Q3 $2014, \wedge \wedge$ a percentage deviation from long-run polynomial trend, For all the variables, at least one test (KPSS, ADF) indicated stationarity. KPSS test with a constant implies that reference rate is $I(1)$, while the test with a trend at the margin of the significance indicates that we could decide $I(0)$. Based on ADF test with a constant at 0.05 significance level, it might be assumed $I(0)$ too when selecting a lag of 8 quarters and testing down from the maximum lag order by the criterion of modified AIC. $I(0)$ is also not rejected basing on KPSS test (both with a constant and including trend) at 0.05 significance level after 2005. Nevertheless, the authors carried out a robustness analysis by estimating Taylortype rules with first differences of the reference rate. The conclusions of the research were not altered.

Source: The author's own calculations on Gretl Software (v. 1.9.92) 